\title{
PENGARUH PENGEMBANGAN KARIR, KOMPENSASI, DAN IKLIM ORGANISASI TERHADAP LOYALITAS KARYAWAN
}

\author{
Ni Putu Dian Purnamasari ${ }^{1}$ \\ Desak Ketut Sintaasih ${ }^{2}$ \\ ${ }^{1,2}$ Fakultas Ekonomi dan Bisnis Universitas Udayana (Unud), Bali, Indonesia \\ email: purnamasaridian909@gmail.com
}

\begin{abstract}
ABSTRAK
Tujuan penelitian ini adalah untuk menganalisis pengaruh pengembangan karir, kompensasi, dan iklim organisasi terhadap loyalitas karyawan. Penelitian dilakukan pada Bellevue Heritage Villas Nusa Dua, Bali, dengan responden sebanyak 40 orang karyawan. Pengumpulan data menggunakan metode wawancara dan kuesioner, serta teknik analisis data yang digunakan adalah regresi linier berganda. Hasil penelitian menunjukkan bahwa pengembangan karir berpengaruh positif dan signifikan terhadap loyalitas karyawan. Hasil ini mengindikasikan semakin baik sistem pengembangan karir perusahaan maka loyalitas karyawan juga akan semakin kuat. Kompensasi dan iklim organisasi juga berpengaruh positif dan signifikan terhadap loyalitas karyawan. Dari ketiga variabel yang dianalisis ternyata kompensasi berpengaruh paling kuat terhadap loyalitas karyawan diikuti oleh iklim organisasi. Hal ini memberi indikasi bahwa semakin baik sistem kompensasi yang diterapkan perusahaan demikian pula iklim organisasinya maka loyalitas karyawan juga akan semakin kuat. Implikasi praktis hasil penelitian ini bahwa perusahaan yang mengharapkan karyawan yang loyal maka harus menerapkan sistem kompensasi yang baik didukung dengan iklim organisasi yang kondusif. Sistem pengembangan karir juga harus jelas dan dikomunikasikan kepada seluruh karyawan.
\end{abstract}

Kata kunci : pengembangan karir, kompensasi, iklim organisasi, dan loyalitas karyawan

\begin{abstract}
The purpose of this study was to analyze the influence of career development, compensation, and organizational climate on employee loyalty. The study was conducted at Bellevue Heritage Villas Nusa Dua, Bali, with 40 employees as respondents. Data collection uses interview and questionnaire methods, and the data analysis technique used is multiple linear regression. The results showed that career development had a positive and significant effect on employee loyalty. These results indicate that the better the career development system of the company, the employee loyalty will also be stronger. Compensation and organizational climate also have a positive and significant effect on employee loyalty. Of the three variables analyzed, compensation turned out to have the strongest influence on employee loyalty followed by organizational climate. This gives an indication that the better the compensation system applied by the company as well as the organizational climate, the employee loyalty will also be stronger. The practical implication of the results of this study is that companies that expect loyal employees must implement a compensation system that is well supported by a conducive organizational climate. The career development system must also be clear and communicated to all employees.

Keywords: career development, compensation, organizational culture, employee loyalty
\end{abstract}




\section{PENDAHULUAN}

Karyawan merupakan aset berharga dalam organisasi karena mereka adalah sumber keunggulan kompetitif perusahaan. Karyawan yang berkompeten dapat meningkatkan kinerja dan produktivitas perusahaan namun karyawan yang kurang berkompeten dapat menyebabkan perusahaan yang sudah berkembang menjadi kurang maksimal dalam mencapai tujuannya. Melalui pemanfaatan SDM yang efisien dan efektif, perusahaan akan mampu bertahan dalam meraih kesuksesan. Di era globalisasi saat ini dengan pasar tenaga kerja yang dinamis, menjaga karyawan yang baik dan mengembangkan loyalitas karyawan menjadi semakin penting, karena karyawan memiliki peran utama dalam setiap kegiatan operasional perusahaan.

Villa adalah salah satu perusahaan yang mengandalkan SDM dalam kegiatan operasional sehari-hari. Villa sebagai salah satu usaha dalam industri pelayanan/jasa yang memiliki karyawan yang terampil akan memberikan pelayanan yang terbaik. Bellevue Heritage Villas Nusa Dua, Bali adalah salah satu villa yang terletak di Jalan Darmawangsa No 138A, Ling Menesa Nusa Dua, Bali yang merupakan pusat kawasan villa yang dikelilingi pantai dengan pemandangan yang indah dan asri.

Banyaknya industri pariwisata khususnya di bidang pelayanan/jasa yang ada di Bali semakin memperkuat perusahaan untuk tetap meningkatkan kualitas pelayanan dengan cara memberikan pelayanan yang memuaskan kepada pelanggan melalui karyawan yang memiliki loyalitas tinggi terhadap perusahaan. Karyawan yang memiliki loyalitas tinggi menjadi penting untuk dapat memberikan pelayanan yang baik. (Evawati, 2013). Pada dasarnya loyalitas merupakan kesetiaan, pengabdian, dan kepercayaan yang diberikan kepada seseorang atau lembaga yang didalamnya terdapat rasa cinta dan tanggung jawab untuk berusaha memberikan pelayanan dan perilaku terbaik untuk perusahaan (Leblecbici, 2012)

Karyawan yang loyal terhadap perusahaan adalah karyawan yang mempunyai kemauan bekerja sama yang berarti kesedian mengorbankan diri melibatkan adanya kesadaran untuk mengabdikan diri kepada perusahaan, pengabdian ini akan selalu menyokong peran serta karyawan dalam perusahaan. Karyawan dengan tingkat loyalitas yang tinggi akan dihargai oleh perusahaan untuk kelangsungan hidup perusahaan dalam menentukan maju mundurnya perusahaan di masa mendatang (Mursita, 2015).

Loyalitas karyawan Bellevue Heritage Villas Nusa Dua, Bali dapat dikatakan rendah karena karyawan tidak mematuhi peraturan perusahaan, tidak dapat menyelesaikan pekerjaan tepat waktu, karyawan tidak jujur dalam melaporkan hasil pekerjaannya, tidak adanya komunikasi antara karyawan dengan atasan, serta banyaknya karyawan yang berhenti bekerja dalam waktu 3 bulan terakhir setelah tanda tangan kontrak tanpa sepengetahuan atasan. Hal ini disebabkan karena karyawan merasa tidak puas dengan pengembangan karir yang ada di perusahaan untuk karyawan yang sudah bekerja lebih dari 2 tahun, pemberian kompensasi yang kurang merata, dan iklim organisasi yang ada di perusahaan yang kurang nyaman karena karyawan bersaing untuk mendapatkan jenjang karir sehingga ada beberapa karyawan yang tidak jujur dengan sesama rekan kerja. 
Hasil dari penelitian awal terhadap 7 orang responden maka ditemukan indikasi adanya tingkat loyalitas yang belum maksimal pada karyawan Bellevue Heritage Villas Nusa Dua, Bali keyakinan tersebut dapat dilihat masalah mengenai loyalitas karyawan yang merupakan keluhan karyawan yang diutarakan karyawan di perusahaan yaitu adanya ketidakkonsistenan karyawan dalam bekerja dimana ada kecenderungan bahwa karyawan melaksanakan tugas tanpa adanya inisiatif dari diri sendiri, kurangnya pengembangan karir yang diterapkan oleh atasan sehingga semangat karyawan untuk meningkatkan prestasi kerja berkurang, merasa kurang puas atas tunjangan, kurang adanya pembinaan oleh atasan hal ini dikarenakan atasan sering melakukan perjalanan dinas ke luar daerah, rendahnya dukungan yang diberikan oleh anggota organisasi baik dari atasan maupun sesama anggota dalam memberikan bantuan dan arahan.

Berdasarkan uraian tersebut, menarik untuk diteliti lebih jauh pengaruh pengembangan karir, kompensasi, dan iklim organisasi terhadap loyalitas karyawan Bellevue Heritage Villas Nusa Dua, Bali. Hal yang perlu diperhatikan dalam meningkatkan loyalitas karyawan adalah pengembangan karir yang ada di perusahaan. Dari hasil penelitian (Florence, 2010), ditemukan bahwa pengembangan karir berpengaruh positif terhadap loyalitas karyawan karena pengembangan karir merupakan metode perencanaan teroganisisir yang digunakan untuk menyesuaikan tujuan karyawan dengan kebutuhan bisnis dari suatu organisasi untuk meningkatakan loyalitasnya. Kaseger (2013) menyatakan bahwa pengembangan karir merupakan pendekatan formal yang dilakukan organisasi untuk menjamin orang-orang dalam organisasi untuk memiliki kualifikasi, kemampuan, dan pengalaman yang sesuai ketika dibutuhkan. Semakin baik pengembangan karir yang ada di perusahaan, semakin tinggi kemauan karyawan untuk loyal terhadap perusahaan. Para karyawan menginginkan pengembangan karir yang jelas untuk mengungkapkan minat, kepribadian, dan kemampuannya dalam bekerja.

Kompensasi adalah salah satu faktor yang dapat menumbuhkan loyalitas karyawan dalam perusahaan. Kompensasi adalah segala sesuatu yang diterima karyawan sebagai balas jasa atas kerja yang di berikan kepada perusahaan (Kurniawan dkk., 2013). Berdasarkan penelitian yang dilakukan oleh Aityan \& Gupta (2011) bahwa kompensasi berpengaruh positif terhadap loyalitas karyawan. Apabila karyawan merasa tidak loyal, karyawan tidak bekerja seperti seharusnya, dan pada akhirnya perusahaan akan sulit mempertahankan karyawan, dan juga sulit mengharapkan loyalitasnya.

Faktor lain yang dapat menjadikan karyawan dapat bersikap loyal terhadap perusahaan yaitu iklim organisasi yang baik. Iklim organisasi pada dasarnya akan mampu memunculkan suasana kerja yang menyenangkan, karena iklim organisasi yang kondusif akan mendorong karyawan untuk bekerja dengan baik (Frimansah \& Santy, 2011) Menciptakan sebuah iklim organisasi yang mampu membawa para anggotanya untuk meningkatkan prestasi dalam rangka pencapaian tujuan organisasi bukan merupakan hal yang mudah, karena pada dasarnya manusia memiliki karakteristik tingkah laku yang berbeda sesuai dengan tingkat kebutuhannya (Sullaida, 2010). Hasil penelitian Dewi (2016) menyatakan bahwa iklim organisasi berpengaruh positif terhadap loyalitas karyawan. Dapat dijelaskan 
jika iklim organisasi di perusahaan baik, maka loyalitas karyawan juga semakin baik

Teori pertukaran sosial (the social exchange theory) menyatakan bahwa ketika organisasi mengurus karyawan, maka ada hubungan pertukaran sosial yang menjanjikan untuk meningkatkan kinerja organisasi. Karyawan akan merasa memiliki kewajiban untuk melakukan timbal balik kepada perusahaan ketika karyawan menerima emosional sosial dan sumber daya ekonomi dari perusahaan. Karyawan yang diberdayakan dan diberi pelatihan akan mendedikasikan tenaga, perasaan, dan sumber daya kognitif mereka untuk kinerja yang lebih baik.

Teori pertukaran sosial akan mengimplikasikan bahwa karyawan diperlakukan dengan baik oleh perusahaan sehinga karyawan memiliki komitmen untuk memberikan balasan dengan perilaku positif melalui kinerja karyawan (Cropanzano \& Mitchell, 2005). Teori pertukaran sosial menggambarkan unsurunsur dan proses dengan melibatkan orang-orang untuk tujuan mendapatkan imbalan.

Teori ini sejalan dengan prinsip dari Teori Keadilan yang menunjukkan kepada seseorang merasa puas atau tidak puas atas suatu situasi tergantung pada perasaan adil atau tidak adil dengan cara membandingkan dirinya dengan orang lain pada tingkat dan jenis pekerjaan yang sama, pada tempat yang sama maupun berbeda (Bangun, 2012: 329).

Kedua teori ini berkaitan dengan variabel pengembangan karir, kompensasi, dan iklim organisasi yang nantinya akan berpengaruh terhadap loyalitas karyawan. Semakin adil perusahaan dalam menerapkan pengembangan karir dan pemberian kompensasi maka semakin berkeinginan karyawan untuk tetap loyal terhadap perusahaan. Begitupula dengan iklim organisasi yang baik didapatkan oleh karyawan maka karyawan akan semakin nyaman untuk tetap bekerja di perusahaan tersebut.

Loyalitas karyawan pada suatu perusahaan ditunjukkan dengan komitmen karyawan di dalam perusahaan, loyalitas dalam berorganisasi bisa terjadi karena ada faktor-faktor yaitu dari diri sendiri dan organisasi (Evawati, 2013).

Simbolon (2015) mengindikasikan bahwa loyalitas merupakan kesetiaan yang dicerminkan oleh kesediaan karyawan menjaga dan membela organisasi di dalam maupun di luar pekerjaan dari orang-orang yang tidak bertanggung jawab.

Loyalitas adalah sifat yang dimiliki oleh seorang karyawan dan akan muncul pada saat bekerja dalam sebuah organisasi atau perusahaan, dalam kehidupan sehari-hari baik disadari maupun tidak, loyalitas adalah bagian dari kehidupan manusia sendiri (Aityan \& Gupta, 2011). Loyalitas adalah berbagai bentuk peran serta anggota organisasi dalam menggunakan tenaga dan pikiran serta waktunya dalam mewujudkan tujuan organisasi (Martiwi \& Mardalis, 2013).Berdasarkan uraian tersebut dapat disimpulkan bahwa loyalitas adalah kesetiaan yang dicerminkan oleh kesediaan karyawan menjaga dan membela organisasi dengan kesadaran, tekad, serta kesanggupan yang dibuktikan dengan sikap dan tingkah laku dalam melaksanakan tugas untuk mewujudkan tujuan organisasi.

Faktor -faktor yang mempengaruhi loyalitas karyawan sebagai berikut. 1) Faktor Rasional, Berkaitan dengan hal-hal yang bisa dijelaskan secara logis, seperti gaji, bonus, jenjang karir, dan fasilitas-fasilitas yang diberikan perusahaan kepada 
karyawan. 2) Faktor Emosional, Berkaitan dengan perasaan atau ekspresi diri seperti pekerjaan yang menantang, lingkungan kerja yang mendukung, perasaan aman karena perusahaan merupakan tempat bekerja dalam jangka panjang, pemimpin yang berkharisma, pekerjaan yang membanggakan, penghargaanpenghargaan yang diberikan perusahaan dan budaya kerja. 3) Faktor Kepribadian, Berkaitan dengan sifat, karakter, tempramen yang dimiliki oleh karyawan. (Murali, Poddar, \& Seema, 2017)

Loyalitas karyawan mempengaruhi kemajuan karyawan dalam memberikan pelayanan kepada pelanggan sehingga perusahaan semakin unggul dalam bersaing, adapun faktor yang mempengaruhi dalam penelitian ini adalah pengembangan karir, kompensasi, dan iklim organisasi. Pengembangan karir berpengaruh positif dan signifikan terhadap loyalitas karyawan, semakin tinggi pengembangan karir yang di dapat oleh karyawan di perusahaan, semakin tinggi kemauan karyawan untuk loyal terhadap perusahaan (Permatasari, 2006)

Penelitian yang dilakukan oleh Dewi (2016) memiliki hasil iklim organisasi berpengaruh positif dan signifikan terhadap loyalitas karyawan. Apabila atasan dan rekan kerja saling mendukung dalam bekerja dan pembagian tugas diberikan sesuai dengan peran masing-masing karyawan sehingga karyawan merasa iklim organisasinya baik maka akan berdampak pada loyalitas karyawan.

Pengembangan karir yang baik dalam rangka mengembangkan karir diri harus dilakukan untuk meraih jenjang tertentu sehingga karyawan akan mempunyai tanggung jawab yang lebih besar di waktu yang akan datang. Para karyawan harus dilatih untuk untuk mengurangi dan menghilangkan kebiasaan jelek atau untuk melatih keterampilan baru yang akan meningkatkatkan kinerja sehingga diharapkan loyalitas terhadap karyawan meningkat (Harlie, 2012).

Penelitian yang dilakukan (Wicoksono, 2013) juga menyatakan bahwa pengembangan karir memiliki pengaruh yang positif dan signifikan terhadap loyalitas karyawan. Hipotesis ini berarti bahwa semakin tinggi pengembangan karir yang didapat oleh karyawan maka semakin tinggi pula loyalitas karyawan tersebut. Berdasarkan hasil empiris pada penelitian sebelumnya, hipotesis yang dapat diajukan dalam penelitian ini adalah :

$\mathrm{H}_{1}$ : Pengembangan karir berpengaruh positif dan signifikan pada loyalitas karyawan.

Kompensasi adalah salah satu elemen penting yang memotivasi karyawan melakukan pekerjaan, dengan pemberian kompensasi yang merata maka karyawan akan termotivasi untuk meningkatkatkan kinerja serta loyalitas terhadap perusahaan (Armanu, W, \& Sudjatno, 2017). Penelitian yang dilakukan oleh Handayani (2015) menyatakan bahwa variabel kompensasi mempunyai pengaruh yang signifikan terhadap loyalitas kerja karyawan pada PT. Putera Lautan Kumala Lines.

Hipotesis ini berarti bahwa semakin tinggi kompensasi yang diberikan kepada karyawan maka semakin tinggi pula loyalitas karyawan tersebut. Berdasarkan hasil empiris pada penelitian terdahulu, hipotesis yang dapat diajukan dalam penelitian ini adalah :

$\mathrm{H}_{2}$ : Kompensasi berpengaruh positif dan signifikan pada loyalitas karyawan. 
Iklim organisasi terkait erat dengan proses menciptakan lingkungan kerja yang kondusif, sehingga dapat tercipta hubungan dan kerjasama yang harmonis diantara seluruh anggota organisasi (Suarningsih, N.L.P., Alamsyah, A., Thoyib, 2011).

Berdasarkan penelitian yang dilakukan oleh Dewi (2016) menyatakan bahwa iklim organisasi berpengaruh positif terhadap loyalitas karyawan. Mursita (2015) juga menyatakan bahwa iklim organisasi berpengaruh positif terhadap loyalitas karyawan yang berarti setiap peningkatan pelaksanaan iklim organisasi sebesar 1 satuan maka akan meningkatkan loyalitas karyawan sebesar 0,818 . Selain itu, hasil dari uji signifikansi individu (Uji t) juga menyatakan bahwa nilai t hitung $>t$ tabel $(8,356>1,984)$ dan Signifikansi $<0,05(0,000<0.05)$ maka $\mathrm{H}_{\mathrm{o}}$ ditolak, jadi dapat disimpulkan bahwa iklim organisasi berpengaruh terhadap loyalitas karyawan.

Rahimic (2013) dan Jyoti (2016) juga menyatakan bahwa iklim organisasi berpengaruh secara positif dan signifikan terhadap loyalitas karyawan. Apabila atasan dan rekan kerja saling mendukung dalam bekerja dan pembagian tugas diberikan sesuai dengan peran masing-masing karyawan sehingga karyawan merasa iklim organisasinya baik maka akan berdampak pada loyalitas karyawan. $\mathrm{H}_{3}$ : Iklim organisasi berpengaruh positif dan signifikan pada loyalitas karyawan.

\section{METODE PENELITIAN}

Penelitian ini menggunakan pendekatan kuantitatif yang bersifat asosiatif untuk meneliti keterkaitan pengembangan karir, kompensasi dan iklim organisasi dengan loyalitas karyawan. Penelitian dilakukan di Bellevue Heritage Villas Nusa Dua, Bali yang belokasi di Jalan Darmawangsa no 138A, Ling Menesa Nusa DuaBali, perusahaan yang bergerak di bidang jasa penginapan.

Berdasarkan kerangka konseptual dan hipotesis yang telah dirumuskan, maka variabel yang diambil dalam penelitian ini dapat dikelompokkan menjadi variabel bebas dan variabel terikat. Variabel bebas dalam penelitian ini yaitu pengembangan karir, kompensasi, dan iklim organisasi sedangkan variabel terikat yaitu loyalitas karyawan

Loyalitas karyawan adalah tekad dan kesanggupan karyawan Bellevue Heritage Villas Nusa Dua Bali dalam mentaati, melaksanakan dan mengamalkan semua ketentuan dan peraturan perusahaan dengan penuh kesadaran dan tanggung jawab yang dibuktikan dalam sikap dan tingkah laku sehari-hari serta dalam tindakan melaksanakan tugas

Loyalitas karyawan dalam penelitian ini diukur dengan indikator-indikator sebagai berikut 1) Kepatuhan, yaitu kesanggupan karyawan Villa untuk mematuhi segala peraturan yang belaku serta sanggup tidak melanggar larangan yang ditentukan. 2) Bertanggung jawab, yaitu kesanggupan karyawan Villa dalam menyelesaikan pekerjaan yang dibebankan kepadanya dengan tepat waktu, dan berani mengambil risiko untuk keputusan yang dibuat atau tindakan yang dilakukan. 3) Pengabdian, yaitu sumbangan pemikiran melaui pemberian ide-ide secara berkelanjutan oleh karyawan Villa kepada perusahaan. 4) Kejujuran, yaitu perilaku jujur yang ditunjukkan kayawan dalam menjalankan pekerjaan sesuai 
dengan peraturan yang telah ditetapkan perusahaan dengan cara melaporkan hasil pekerjaan kepada atasan sesuai dengan prosedur.

Pengembangan karir adalah proses jenjang karir yang dilalui sesuai dengan kompetensi, minat, keadilan, kepedulian, serta pendidikan karyawan melalui penerapan model yang tepat untuk mendapatkan posisi dan peningkatan status dalam berkarir (Haryani, 2008)

Indikator-indikator yang berkaitan dengan pengembangan karir adalah sebagai berikut. 1) Perlakuan yang adil yaitu suatu sikap pimpinan perusahaan yang memberikan kesempatan yang sama kepada karyawan untuk mengembangkan karirnya. 2) Kepedulian atasan yaitu perilaku pimpinan perusahaan yang menghargai hasil kerja dan perkembangan karir karyawan melalui pemberian apresiasi kepada karyawan. 3) Kompetensi adalah kemampuan yang dimiliki karyawan sesuai dengan jenjang karir yang akan dilalui atau posisi karir yang ada di perusahaan. 4) Minat untuk dipromosikan adalah keinginan karyawan untuk meraih sasaran karir yang lebih tinggi dengan cara mendapatkan informasi mengenai promosi jabatan. 5) Pendidikan formal yaitu persyaratan yang harus dipenuhi oleh seorang karyawan dalam suatu perusahaan sesuai dengan jenjang karir.

Kompensasi semua bentuk penghargaan yang diterima oleh karyawan baik secara finansial maupun non finansial meliputi upah, gaji, insentif, dan tunjangan (Dessler, 2015:417). Indikator yang digunakan dalam penelitian ini yaitu : 1) Gaji adalah hak yang diterima oleh karyawan karena partisipasinya pada perusahaan sesuai beban kerja. 2) Insentif adalah tambahan diluar gaji dan upah yang diberikan oleh perusahaan atas kinerja lebih atau standar. 3) Tunjangan adalah kompensasi tambahan yang diberikan berdasarkan kebijakan perusahaan terhadap semua karyawan dalam usaha untuk meningkatkan kesejahteraan karyawan seperti tunjangan hari raya dan tunjangan kesehatan.

Iklim organisasi adalah serangkaian lingkungan kerja di sekitar tempat kerja yang berpengaruh terhadap perilaku seseorang dalam melaksanakan pekerjaan yang akhirnya menjadikan tujuan organisasi cepat tercapai (Cahyono \& Adnyani, 2014)

Beberapa indikator dari iklim organisasi, yaitu: 1) Perilaku atau pola interaksi pimpinan dalam menggerakkan bawahan untuk mencapai tujuan perusahaan. 2) Adanya sikap saling percaya antara karyawan dengan pimpinan perusahaan untuk mempertahankan hubungan yang penuh keyakinan. 3) Para karyawan diajak berkomunikasi mengenai semua masalah dalam kebijakan organisasi yang relevan dengan kedudukan mereka. 4) Adanya suasana kejujuran antar karyawan di dalam organisasi, dimana karyawan mampu mengatakan apa yang ada dipikiran mereka mengenai permasalahan di perusahaan. 5) Para karyawan berbagi informasi yang berhubungan dengan tugas dan wewenang mereka di perusahaan. 6) Karyawan memiliki kebebasan dalam menyampaikan pendapat kepada atasan untuk kemajuan perusahaan. 7) Karyawan menyadari akan risiko pekerjaan yang dilakukan dengan tetap berkomitmen terhadap perusahaan. (Intifada, 2013)

Populasi dalam penelitian ini yaitu seluruh karyawan Bellevue Heritage Villas Nusa Dua, Bali yang berjumlah 40 orang. Sampel dari penelitian ini berjumlah 40 orang. 
Metode penentuan sampel dalam penelitian ini menggunakan sampling jenuh, yaitu teknik penentuan sampel bila semua anggota populasi digunakan sebagai sampel.

Dalam penelitian ini data-data dikumpulkan dengan menggunakan dua metode yaitu metode wawancara dan metode kuesioner yang ditujukan dan disebarkan kepada seluruh responden penelitian. Analisis regresi linier berganda merupakan teknik analisis data yang digunkaan dalam penelitian ini.

Hasil pengujian validitas instrumen penelitian yang ditampilkan menunjukkan bahwa seluruh indikator dalam variabel pengembangan karir, kompensasi, iklim organisasi, dan loyalitas karyawan memiliki nilai pearson correlation yang lebih besar dari angka 0,30 sehingga seluruh indikator tersebut dikatakan telah memenuhi syarat validitas data.

Tabel 1.

Hasil Uji Validitas

\begin{tabular}{|c|c|c|c|c|}
\hline Variabel & Indikator & $\begin{array}{c}\text { Koefisien } \\
\text { Korelasi }\end{array}$ & $\begin{array}{c}\text { Korelasi } \\
\text { Batas }\end{array}$ & Keterangan \\
\hline \multirow{6}{*}{$\begin{array}{l}\text { Pengembangan Karir } \\
\left(\mathrm{X}_{1}\right)\end{array}$} & $\mathrm{X} 1.1$ & 0,821 & 0,3 & Valid \\
\hline & $\mathrm{X} 1.2$ & 0,877 & 0,3 & Valid \\
\hline & $\mathrm{X} 1.3$ & 0,858 & 0,3 & Valid \\
\hline & $\mathrm{X} 1_{.4}$ & 0,879 & 0,3 & Valid \\
\hline & $\mathrm{X} 1.5$ & 0,814 & 0,3 & Valid \\
\hline & $\mathrm{X} 2.1$ & 0,895 & 0,3 & Valid \\
\hline \multirow[t]{3}{*}{ Kompensasi $\left(\mathrm{X}_{2}\right)$} & $\mathrm{X} 2.2$ & 0,822 & 0,3 & Valid \\
\hline & $\mathrm{X} 2.3$ & 0,831 & 0,3 & Valid \\
\hline & $\mathrm{X} 2.4$ & 0,873 & 0,3 & Valid \\
\hline \multirow[t]{9}{*}{ Iklim Organisasi $\left(\mathrm{X}_{3}\right)$} & $\mathrm{X} 3.1$ & 0,898 & 0,3 & Valid \\
\hline & $\mathrm{X} 3.2$ & 0,894 & 0,3 & Valid \\
\hline & $\mathrm{X} 3.3$ & 0,897 & 0,3 & Valid \\
\hline & $\mathrm{X} 3.4$ & 0,890 & 0,3 & Valid \\
\hline & $\mathrm{X} 3.5$ & 0,795 & 0,3 & Valid \\
\hline & $\mathrm{X} 3.6$ & 0,854 & 0,3 & Valid \\
\hline & $\mathrm{X} 3.7$ & 0,896 & 0,3 & Valid \\
\hline & $\mathrm{X} 3.8$ & 0,848 & 0,3 & Valid \\
\hline & $\mathrm{Y}_{1}$ & 0,859 & 0,3 & Valid \\
\hline \multirow[t]{3}{*}{ Loyalitas Karyawan (Y) } & $\mathrm{Y}_{2}$ & 0,893 & 0,3 & Valid \\
\hline & $\mathrm{Y}_{3}$ & 0,897 & 0,3 & Valid \\
\hline & $\mathrm{Y}_{4}$ & 0,871 & 0,3 & Valid \\
\hline
\end{tabular}

Sumber: Data diolah, 2018

Hasil pengujian validitas instrumen penelitian yang ditampilkan menunjukkan bahwa keempat instrumen penelitian yaitu pengembangan karir, kompensasi, iklim organisasi, dan loyalitas karyawan memiliki koefisien cronbach's alpha yang lebih besar dari angka 0,60 sehingga pada kuesioner dapat dikatakan reliabel. 
Tabel 2.

Hasil Uji Reliabilitas

\begin{tabular}{lcc}
\hline \multicolumn{1}{c}{ Variabel } & Cronbach's Alpha & Keterangan \\
\hline Pengembangan Karir $\left(\mathrm{X}_{1}\right)$ & 0,899 & Reliabel \\
Kompensasi $\left(\mathrm{X}_{2}\right)$ & 0,872 & Reliabel \\
Iklim Organisasi $\left(\mathrm{X}_{3}\right)$ & 0,954 & Reliabel \\
Loyalitas Karyawan $(\mathrm{Y})$ & 0,901 & Reliabel \\
\hline
\end{tabular}

Sumber: Data diolah, 2018

\section{HASIL DAN PEMBAHASAN}

Penelitian ini menggunakan sampel jenuh yang dimana seluruh populasi menjadi sampel yaitu 40 karyawan. Dari hasil penelitian yang dilakukan terhadap karyawan Bellevue Heritage Villas Nusa Dua, Bali maka dapat diketahui gambaran karakteristik responden meliputi tujuh aspek, yaitu umur, jenis kelamin, pendidikan, masa kerja, peningkatan jabatan, jabatan sekarang, dan jabatan sebelumnya.

Sebagian besar responden berusia diantara 22-27 tahun dengan persentase sebesar 55,00 persen, sedangkan sedangkan untuk kelompok usia terendah yaitu pada usia 40-45 tahun dengan persentase 10,00 persen.

Berdasarkan jenis kelamin sebagian besar responden adalah laki-laki sebanyak 28 orang dengan persentase 70,00 persen, sedangkan sisanya perempuan sebanyak 12 orang dengan persentase 30,00 persen. Hal ini dikarenakan jam kerja perusahaan yang sampai larut malam.

Sebagian besar responden berdasarkan pendidikan terakhir adalah SMK sebanyak 19 orang dengan persentase 47,50 persen, SMA sebanyak 8 orang dengan persentase 20,00 persen, SMP sebanyak 2 orang dengan persentase 5,00 persen, D1 sebanyak 6 orang dengan persentase 15,00 persen, D3 sebanyak 2 orang dengan persentase 5,00 persen, dan S1 sebanyak 3 orang dengan persentase 7,50 persen. Hal ini berarti Bellevue Heritage Villas Nusa Dua, Bali mempekerjakan karyawan yang sudah mendapatkan pelatihan khusus/training.

Loyalitas karyawan dalam penelitian ini menggunakan 4 pernyataan yang tergolong baik dengan nilai rata-rata 3,46. Nilai rata-rata tertinggi dimiliki oleh pernyataan 1 yaitu sebesar 3,73. Hal ini menunjukan bahwa karyawan Bellevue Heritage Villas Nusa Dua, Bali selalu mematuhi peraturan-peraturan yang ditetapkan oleh perusahaan. Nilai rata-rata terendah terdapat pada pernyataan 3 sebesar 3,15. Hal ini menunjukan bahwa karyawan belum maksimal dalam menyumbangkan pemikiran dan ide kreatif untuk menyelesaikan permasalahan yang ada.

Pengembangan karir diukur dengan menggunakan 5 indikator pernyataan yang tergolong baik memiliki nilai rata-rata 3,57. Sistem pengembangan karir yang baik terutama didukung oleh kondisi adanya karyawan yang memiliki latar belakang pendidikan formal yang cukup untuk mengembangkan karir di perusahaan ini (nilai rata-rata skor 3,85), selain itu ada pula keyakinan karyawan terhadap kompetensi di bidang pekerjaan sekarang (nilai rata-rata skor 3,50), namun nilai 
rata-rata terendah terdapat pada pernyataan atasan selalu mendukung pengembangan karir karyawannya (nilai rata-rata skor 3,20). Hal ini menunjukan bahwa salah satu alasan karyawan terhambat pada peningkatan karir disebabkan karena kurangnya dukungan dari pihak atasan atasan kepada karyawan karyawan dalam jenjang karir, padahal hal tersebut berdampak besar untuk kemajuan perusahaan.

Tabel 3.

Deskripsi Variabel Loyalitas Karyawan

\begin{tabular}{|c|c|c|c|c|c|c|c|c|}
\hline \multirow{2}{*}{ No } & \multirow{2}{*}{ Pernyataan } & \multicolumn{5}{|c|}{ Frekuensi Jawaban Responden } & \multirow{2}{*}{$\begin{array}{c}\text { Rata- } \\
\text { rata }\end{array}$} & \multirow{2}{*}{ Kriteria } \\
\hline & & STS & TS & CS & $\mathbf{S}$ & SS & & \\
\hline 1 & $\begin{array}{l}\text { Selalu mematuhi peraturan } \\
\text { yang ditetapkan oleh } \\
\text { perusahaan }\end{array}$ & 0 & 0 & 19 & 13 & 8 & 3,73 & Tinggi \\
\hline 2 & $\begin{array}{l}\text { Dapat menyelesaikan } \\
\text { pekerjaan dengan tepat } \\
\text { waktu }\end{array}$ & 0 & 0 & 20 & 15 & 5 & 3,63 & Tinggi \\
\hline 3 & $\begin{array}{l}\text { Selalu memberikan } \\
\text { sumbangan pemikiran } \\
\text { dalam menyelesaikan } \\
\text { permasalahan pada } \\
\text { perusahaan }\end{array}$ & 0 & 10 & 15 & 14 & 1 & 3,15 & $\begin{array}{l}\text { Cukup } \\
\text { Tinggi }\end{array}$ \\
\hline 4 & $\begin{array}{l}\text { Pernah ditegur oleh atasan } \\
\text { karena tidak jujur dalam } \\
\text { melaksanakan pekerjaan } \\
\text { dengan melaporkan hasil } \\
\text { pekerjaan tidak sesuai } \\
\text { dengan prosedur }\end{array}$ & 0 & 6 & 17 & 15 & 2 & 3,33 & $\begin{array}{l}\text { Cukup } \\
\text { Tinggi }\end{array}$ \\
\hline Var & el Loyalitas Karyawan & & & & & & 3,46 & Tinggi \\
\hline
\end{tabular}

Tabel 4.

Deskripsi Variabel Pengembangan Karir

\begin{tabular}{|c|c|c|c|c|c|c|c|c|}
\hline \multirow{2}{*}{ No } & \multirow{2}{*}{ Pernyataan } & \multicolumn{5}{|c|}{ Frekuensi Jawaban Responden } & \multirow{2}{*}{$\begin{array}{l}\text { Rata- } \\
\text { Rata }\end{array}$} & \multirow{2}{*}{ Kriteria } \\
\hline & & STS & TS & CS & $\mathbf{S}$ & SS & & \\
\hline 1 & $\begin{array}{l}\text { Perlakuan yang adil dalam } \\
\text { mengembangkan karir di } \\
\text { perusahaan ini. }\end{array}$ & 0 & 6 & 16 & 11 & 7 & 3,48 & Baik \\
\hline 2 & $\begin{array}{l}\text { Atasan yang selalu } \\
\text { mendukung pengembangan } \\
\text { karir karyawan }\end{array}$ & 0 & 7 & 21 & 9 & 3 & 3,20 & $\begin{array}{l}\text { Cukup } \\
\text { Baik }\end{array}$ \\
\hline 3 & $\begin{array}{l}\text { Keyakinan kompetensi di } \\
\text { bidang pekerjaan sekarang }\end{array}$ & 0 & 8 & 9 & 18 & 5 & 3,50 & Baik \\
\hline 4 & $\begin{array}{l}\text { Minat untuk dipromosikan } \\
\text { oleh atasan }\end{array}$ & 0 & 1 & 12 & 20 & 7 & 3,38 & Baik \\
\hline 5 & $\begin{array}{l}\text { Memiliki latar belakang } \\
\text { pendidikan formal yang } \\
\text { cukup }\end{array}$ & 0 & 2 & 11 & 18 & 9 & 3,85 & Baik \\
\hline Var & bel Pengembangan Karir & & & & & & 3,57 & Baik \\
\hline
\end{tabular}


Penilaian responden dengan menggunakan 4 indikator digunakan terhadap variabel kompensasi Bellevue Heritage Villas Nusa Dua, Bali. Kompensasi secara keseluruhan tergolong cukup baik, hal ini dapat dilihat dari keseluruhan rata-rata nilai kompensasi yaitu 3,34. Nilai rata-rata tertinggi ditunjukkan dari karyawan memperoleh jaminan kesehatan selama bekerja di Bellevue Heritage Villas Nusa Dua, Bali (nilai rata-rata skor 3,60). Nilai rata-rata terendah ditunjukkan bahwa karyawan belum mendapat insentif sesuai dengan prestasi kerja yang dicapai (nilai rata-rata skor 2,95).

Tabel 5.

Deskripsi Variabel Kompensasi

\begin{tabular}{|c|c|c|c|c|c|c|c|c|}
\hline \multirow{2}{*}{ No } & \multirow{2}{*}{ Pernyataan } & \multicolumn{5}{|c|}{ Frekuensi Jawaban Responden } & \multirow{2}{*}{$\begin{array}{l}\text { Rata- } \\
\text { rata }\end{array}$} & \multirow{2}{*}{ Kriteria } \\
\hline & & STS & TS & CS & $\mathbf{S}$ & SS & & \\
\hline 1 & $\begin{array}{l}\text { Mendapat gaji sesuai } \\
\text { dengan beban kerja di } \\
\text { perusahaan }\end{array}$ & 0 & 6 & 23 & 9 & 2 & 3.18 & $\begin{array}{c}\text { Cukup } \\
\text { Baik }\end{array}$ \\
\hline 2 & $\begin{array}{l}\text { Mendapat insentif sesuai } \\
\text { dengan prestasi kerja yang } \\
\text { dicapai }\end{array}$ & 0 & 8 & 27 & 4 & 1 & 2.95 & $\begin{array}{c}\text { Cukup } \\
\text { Baik }\end{array}$ \\
\hline 3 & $\begin{array}{l}\text { Mendapat tunjangan hari } \\
\text { raya setiap tahun di } \\
\text { perusahaan }\end{array}$ & 0 & 2 & 18 & 13 & 7 & 3.36 & $\begin{array}{c}\text { Cukup } \\
\text { Baik }\end{array}$ \\
\hline 4 & $\begin{array}{l}\text { Memperoleh jaminan } \\
\text { kesehatan selama bekerja } \\
\text { di perusahaan ini }\end{array}$ & 0 & 0 & 20 & 16 & 4 & 3.60 & Baik \\
\hline Var & bel Kompensasi & & & & & & 3.34 & $\begin{array}{c}\text { Cukup } \\
\text { Baik }\end{array}$ \\
\hline
\end{tabular}

Nilai rata-rata terendah terdapat pada kondisi karyawan merasa pemimpin atau atasannya belum bisa berkomunikasi dengan baik mengenai semua permasalahan yang dihadapi kepada karyawan (nilai rata-rata skor 3,73).

Metode regresi linier berganda digunakan dalam penelitian ini untuk mengetahui pengaruh Pengembangan Karir $\left(\mathrm{X}_{1}\right)$, Kompensasi $\left(\mathrm{X}_{2}\right)$, Iklim Organisasi $\left(\mathrm{X}_{3}\right)$ dan Loyalitas Karyawan (Y). Metode ini diuji menggunakan sistem komputer berupa SPSS versi 24.0. Hasil dari analisis regresi linier berganda dapat dilihat pada Tabel 7.

Dari data pada Tabel 7 diketahui bahwa nilai $\beta_{1}$ adalah sebesar 0,194 menunjukkan adanya pengaruh positif pengembangan karir $\left(\mathrm{X}_{1}\right)$ terhadap loyalitas karyawan (Y). Nilai $\beta_{2}$ adalah sebesar 0,492 menunjukkan adanya pengaruh positif kompensasi $\left(\mathrm{X}_{2}\right)$ terhadap loyalitas karyawan $(\mathrm{Y})$. Nilai $\beta_{3}$ adalah sebesar 0,181 menunjukkan adanya pengaruh positif iklim organisasi $\left(\mathrm{X}_{3}\right)$ terhadap loyalitas karyawan (Y). Dari hasil tersebut, maka variabel pengembangan karir, kompensasi, dan iklim organisasi berepengaruh terhadap loyalitas karyawan Bellevue Heritage Villas Nusa Dua, Bali. 
Tabel 6.

Deskripsi Variabel Iklim Organisasi

\begin{tabular}{|c|c|c|c|c|c|c|c|c|}
\hline \multirow{2}{*}{ No } & \multirow{2}{*}{ Pernyataan } & \multicolumn{5}{|c|}{ Frekuensi Jawaban Responden } & \multirow{2}{*}{$\begin{array}{l}\text { Rata- } \\
\text { rata }\end{array}$} & \multirow{2}{*}{ Kriteria } \\
\hline & & STS & TS & CS & $\mathbf{S}$ & SS & & \\
\hline 1 & $\begin{array}{l}\text { Pimpinan menunjukkan } \\
\text { perilaku yang baik terhadap } \\
\text { semua karyawan }\end{array}$ & 0 & 1 & 15 & 18 & 6 & 3.73 & Baik \\
\hline 2 & $\begin{array}{l}\text { Percaya dengan sesama rekan } \\
\text { kerja saat melaksanakan } \\
\text { pekerjaan }\end{array}$ & 0 & 5 & 15 & 20 & 40 & 4.38 & $\begin{array}{l}\text { Sangat } \\
\text { Baik }\end{array}$ \\
\hline 3 & $\begin{array}{l}\text { Pimpinan selalu } \\
\text { berkomunikasi dengan baik } \\
\text { kepada bawahan mengenai } \\
\text { semua permasalahan } \\
\text { perusahaan. }\end{array}$ & 0 & 1 & 17 & 19 & 3 & 3.60 & Baik \\
\hline 4 & $\begin{array}{l}\text { Selalu jujur terhadap rekan } \\
\text { kerja }\end{array}$ & 0 & 2 & 6 & 14 & 18 & 4.20 & $\begin{array}{l}\text { Sangat } \\
\text { Baik }\end{array}$ \\
\hline 5 & Selalu jujur terhadap pimpinan & 0 & 0 & 9 & 25 & 6 & 3.93 & Baik \\
\hline 6 & $\begin{array}{l}\text { Sesama rekan kerja selalu } \\
\text { berbagi informasi mengenai } \\
\text { pekerjaan }\end{array}$ & 0 & 3 & 7 & 20 & 13 & 4.15 & Baik \\
\hline 7 & $\begin{array}{l}\text { Diberi kebebasan oleh atasan } \\
\text { untuk menyampaikan } \\
\text { pendapat }\end{array}$ & 0 & 1 & 10 & 18 & 11 & 3.98 & Baik \\
\hline 8 & $\begin{array}{l}\text { Menyadari risiko atas } \\
\text { pekerjaan yang dilakukan }\end{array}$ & 0 & 0 & 9 & 22 & 9 & 4.00 & Baik \\
\hline Varis & bel Iklim Organisasi & & & & & & 3.99 & Baik \\
\hline
\end{tabular}

Tabel 7.

Hasil Analisis Regresi Linier Berganda

\begin{tabular}{|c|c|c|c|c|c|c|}
\hline \multicolumn{7}{|c|}{ Coefficients $^{\mathrm{a}}$} \\
\hline \multirow{2}{*}{\multicolumn{2}{|c|}{ Model }} & $\begin{array}{r}\text { Uns } \\
\text { C }\end{array}$ & $\begin{array}{l}\text { lardized } \\
\text { icients }\end{array}$ & $\begin{array}{l}\text { Standardized } \\
\text { Coefficients }\end{array}$ & $\mathbf{t}$ & Sig. \\
\hline & & B & Std. Error & Beta & & \\
\hline \multicolumn{2}{|l|}{ (Constant) } & -1.989 & 1.406 & & -1.415 & .166 \\
\hline \multicolumn{2}{|c|}{$\begin{array}{l}\text { Pengembangan } \\
\text { Karir }\left(X_{1}\right)\end{array}$} & 0,194 & 0,077 & 0,260 & 2.515 & .017 \\
\hline \multicolumn{2}{|c|}{$\operatorname{Kompensasi}\left(\mathrm{X}_{2}\right)$} & 0,492 & 0,117 & 0,444 & 4.194 & .000 \\
\hline $\begin{array}{l}\text { Iklim } \\
\text { Organisasi }\left(\mathrm{X}_{3}\right) \\
\text { Loyalitas Karya } \\
\text { (Y) }\end{array}$ & \multicolumn{5}{|c|}{$\begin{array}{l}\text { Loyalitas Karyawan } \\
\text { (Y) }\end{array}$} & .001 \\
\hline R Square & \multicolumn{6}{|l|}{$=0,776$} \\
\hline F Hitung & \multicolumn{6}{|l|}{$=46,059$} \\
\hline Signifikansi F & \multicolumn{6}{|l|}{$=0,000$} \\
\hline
\end{tabular}


Hasil uji asumsi klasik yang terdiri dari hasil uji normalitas menunjukkan bahwa nilai Asymp. Sig. (2-tailed) lebih besar dari taraf signifikansi yang ditetapkan yaitu 5 persen $(0,05)$, sebesar $0,184>0,05$ yang artinya data berdistribusi normal.

Hasil uji multikolinieritas menunjukkan nilai VIF dari variabel pengembangan karir $\left(\mathrm{X}_{1}\right)$, kompensasi $\left(\mathrm{X}_{2}\right)$ dan iklim organisasi $\left(\mathrm{X}_{3}\right)$. Berdasarkan tabel di atas didapat bahwa variabel pengembangan karir memiliki tolerance lebih besar dari $0,10(0,537>0,10)$ dan VIF lebih kecil dari $10(1,862<10)$.

Variabel kompensasi memiliki tolerance lebih besar dari $0,10(0,513>0,10)$ dan VIF lebih kecil dari $10(1,951<10)$. Variabel iklim organisasi memiliki tolerance lebih besar dari $0,10(0,607>0,10)$ dan VIF lebih kecil dari $10(1,646<10)$. Hal ini berarti model persamaan regresi bebas dari multikolinieritas.

Nilai Sig. dari variabel pengembangan karir $\left(\mathrm{X}_{1}\right)$ sebesar 0,468, kompensasi $\left(\mathrm{X}_{2}\right)$ sebesar 0,120, dan iklim organisasi $\left(\mathrm{X}_{3}\right)$ sebesar 0,090. Nilai tersebut lebih besar dari 0,05 yang berarti tidak terdapat pengaruh antara variabel independen terhadap absolute residual. Dengan demikian, model yang dibuat tidak mengandung gejala heteroskedastisitas.

Hasil uji ketepatan model yaitu Uji $\mathrm{F}$ dapat dilihat nilai signifikansi $\mathrm{F}$ adalah sebesar 0,000 lebih kecil dari $0.05(\mathrm{P}$ value $\mathrm{F}<\alpha)$, yang berarti variabel independen yaitu pengembangan karir $\left(\mathrm{X}_{1}\right)$, kompensasi $\left(\mathrm{X}_{2}\right)$, dan iklim organisasi $\left(\mathrm{X}_{3}\right)$ berpengaruh signifikan secara serempak atau bersama-sama terhadap variabel dependen yaitu loyalitas karyawan (Y), sehingga penelitian ini dapat dikatakan memenuhi uji kelayakan model atau model penelitian dinyatakan layak digunakan sebagai model regresi.

Hasil uji heteroskedastisitas menunjukkan nilai menunjukkan bahwa nilai Sig. dari variabel pengembangan karir $\left(\mathrm{X}_{1}\right)$ sebesar 0,468 , kompensasi $\left(\mathrm{X}_{2}\right)$ sebesar 0,120 , dan iklim organisasi $\left(\mathrm{X}_{3}\right)$ sebesar 0,090 . Nilai tersebut lebih besar dari 0,05 yang berarti tidak terdapat pengaruh antara variabel independen terhadap absolute residual. Dengan demikian, model yang dibuat tidak mengandung gejala heteroskedastisitas.

Hasil uji $\mathrm{F}$ dijelaskan dengan nilai signifikansi $\mathrm{F}<\alpha=0,05$ maka model ini dikatakan layak atau variabel bebas mampu menjelaskan variabel terikat, uji $\mathrm{F}$ dapat dilihat pada Tabel 4.12. Berdasarkan uji $\mathrm{F}$, diketahui nilai signifikansi $\mathrm{F}$ adalah sebesar 0,000 lebih kecil dari 0.05 ( $\mathrm{P}$ value $\mathrm{F}<\alpha$ ), yang berarti variabel independen yaitu pengembangan karir $\left(\mathrm{X}_{1}\right)$, kompensasi $\left(\mathrm{X}_{2}\right)$, dan iklim organisasi (X3) berpengaruh signifikan secara serempak atau bersama-sama terhadap variabel dependen yaitu loyalitas karyawan (Y), sehingga penelitian ini dapat dikatakan memenuhi uji kelayakan model atau model penelitian dinyatakan layak digunakan sebagai model regresi.

Nilai Adjusted $R$ Square adalah sebesar 0.776 yang artinya sebesar 77,6 persen variabel loyalitas karyawan dipengaruhi oleh pengembangan karir, kompensasi, dan iklim organisasi, sedangkan sisanya sebesar 22,4 persen dipengaruhi oleh faktor-faktor lain yang tidak dimasukkan ke dalam model penelitian.

Berdasarkan hasil uji hipotesis, diketahui bahwa variabel pengembangan karir $\left(\mathrm{X}_{1}\right)$ memiliki nilai koefisien beta positif sebesar 0,260 dengan nilai 
signifikansi 0,017. Nilai Sig. t 0,017<0,05 mengindikasikan bahwa pengembangan karir $\left(\mathrm{X}_{1}\right)$ berpengaruh positif dan signifikan terhadap loyalitas karyawan $(\mathrm{Y})$. Dengan demikian, $\mathrm{H}_{1}$ diterima.

Nilai signifikan untuk kompensasi memiliki nilai koefisien beta positif sebesar 0,444 dengan nilai signifikansi 0,000. Nilai Sig. t $0,000<0,05$ mengindikasikan bahwa kompensasi $\left(\mathrm{X}_{2}\right)$ berpengaruh positif dan signifikan terhadap loyalitas karyawan (Y). Dengan demikian, $\mathrm{H}_{2}$ diterima.

Nilai signifikan untuk iklim organisasi yakni nilai koefisien beta positif sebesar 0,334 dengan nilai signifikansi sebesar 0,001. Nilai Sig. t 0,001<0,05 mengindikasikan bahwa iklim organisasi $\left(\mathrm{X}_{3}\right)$ berpengaruh positif dan signifikan terhadap loyalitas karyawan (Y). Dengan demikian, $\mathrm{H}_{3}$ diterima.

Hasil pengujian hipotesis terbukti bahwa pengembangan karir berpengaruh positif terhadap loyalitas karyawan. Hal ini berarti apabila pengembangan karir semakin baik maka loyalitas karyawan di Bellevue Heritage Villas Nusa Dua, Bali akan meningkat dan sebaliknya, jika tingkat pengembangan karir tidak baik maka loyalitas karyawan yang dimiliki karyawan di Bellevue Heritage Villas Nusa Dua, Bali akan menurun. Dari hasil penelitian ini terbukti bahwa pengembangan karir dapat dikatakan baik yaitu karyawan sudah mendapat perlakuan yang adil oleh atasan untuk mengembangkan karir, atasan selau memberi dukungan kepada karyawan, karyawan yakin memiliki kompeten dalam bidang pekerjaannya, karyawan berminat untuk dipromosikan atasan, dan karyawan memilki latar belakang pendidikan formal untuk mengembangkan karir. Terpenuhinya pengembangan karir yang baik akan berpengaruh positif terhadap meningkatnya loyalitas karyawan di Bellevue Heritage Villas Nusa Dua, Bali.

Hasil penelitian ini sesuai dengan penelitian sebelumnya yang dilakukan oleh Wicoksono (2013) menyatakan bahwa pengembangan karir berpengaruh positif dan signifikan terhadap loyaliats karyawan. Disaat perusahaan memberikan jenjang karir yang adil terhadap karyawan maka akan tercipta loyalitas yang tinggi terhadap perusahaan. Karyawan yang mendapatkan jenjang karir yang baik akan menunjukkan perilaku loyal terhadap perusahaan. Hal ini dapat disimpulkan bahwa dengan adanya pengembangan karir yang baik akan berpengaruh positif terhadap loyalitas karyawan di Bellevue Heritage Villas Nusa Dua, Bali.

Hasil pengujian hipotesis terbukti bahwa kompensasi berpengaruh positif terhadap loyalitas karyawan yang berarti apabila pemberian kompensasi semakin baik maka loyalitas karyawan di Bellevue Heritage Villas Nusa Dua, Bali akan meningkat dan sebaliknya, jika pemberian kompensasinya buruk maka loyalitas karyawan yang dimiliki karyawan Bellevue Heritage Villas Nusa Dua, Bali akan menurun. Hasil dari penelitian ini terbukti bahwa pemberian kompensasi dapat dikatakan baik yaitu, gaji yang didapat karyawan sesuai dengan beban kerja, mendapat insentif sesuai dengan prestasi kerja, mendapatkan tunjangan hari raya setiap tahun, dan mendapat jaminan kesehatan selama bekerja. Terpenuhinya kompensasi dengan baik akan berpengaruh positif terhadap loyalitas karyawan di Bellevue Heritage Villas Nusa Dua, Bali.

Hasil penelitian ini sesuai dengan penelitian sebelumnya yang dilakukan oleh Purwandari (2008), Wibawa \& Stephani (2014), Ramadhani \& Rahardjo (2017) menyatakan bahwa kompensasi berpengaruh positif dan signifikan terhadap 
loyalitas karyawan. Faktor yang dapat mempengaruhi loyalitas karyawan yaitu pemberian gaji, insentif, jaminan kesehatan, dan tunjangan hari raya. juga menyatakan bahwa kompensasi berpengaruh positif dan signifikan terhadap loyalitas karyawan. Hal ini dapat disimpulkan bahwa pemberian kompensasi yang baik akan berpengaruh positif terhadap loyalitas karyawan di Bellevue Heritage Villas Nusa Dua, Bali

Iklim organisasi berpengaruh positif terhadap loyalitas karyawan yang berarti apabila iklim organisasi semakin baik maka loyalitas karyawan di Bellevue Heritage Villas Nusa Dua, Bali akan meningkat dan sebaliknya, jika iklim organisasi buruk maka loyalitas karyawan di Bellevue Heritage Villas Nusa Dua, Bali akan menurun. Hasil dari penelitian ini terbukti bahwa iklim organisasi yang dirasakan karyawan Bellevue Heritage Villas Nusa Dua, Bali akan semakin tinggi, terutama dengan rasa percaya karyawan sesama rekan kerja di perusahaan. Karyawan merasa nyaman dengan sikap percaya satu sama lain saat melakukan pekerjaan sehingga membuat karyawan ingin tetap loyal terhadap perusahaan. Hal tersebut bisa dikatakan iklim organisasi memiliki pengaruh yang positif terhadap loyalitas karyawan di Bellevue Heritage Villas Nusa Dua, Bali

Hasil penelitian ini sesuai dengan penelitian sebelumnya yang dilakukan oleh Dewi, (2016) yang menyatakan bahwa iklim organisasi berpengaruh positif terhadap loyalitas karyawan. Untuk meningkatkan performa perusahaan, perusahaan memperhatikan karyawan dengan baik dan menyediakan lingkungan yang suportif untuk pengembangan karyawan, sehingga iklim organisasi semakin baik dan bisa meningkatkan loyalitas terhadap perusahaan. (Mursita, 2015) juga menyatakan bahwa iklim organisasi berpengaruh positif terhadap loyalitas karyawan.

Implikasi penelitian ini menekankan pada manfaat dari hasil penelitian yang dapat dijadikan sebagai strategi untuk menciptakan loyalitas karyawan Bellevue Heritage Villas Nusa Dua, Bali. Beberapa implikasi dari hasil penelitian ini, yakni pertama terbukti bahwa responden merasakan pengembangan karir baik untuk bekerja di Bellevue Heritage Villas Nusa Dua, Bali karena karyawan diperlakukan secara adil untuk mengembangkan karir sehingga para karyawan memiliki keinginan yang tinggi untuk loyal bekerja di Bellevue Heritage Villas Nusa Dua, Bali.

Kedua, melalui penelitian ini diketahui bahwa pemberian kompensasi di Bellevue Heritage Villas Nusa Dua, Bali tergolong baik. Kompensasi yang diberikan harus sesuai dengan hasil produktifitas perusahaan atau sesuai dengan proporsi karyawan, dan mampu membayar sesuai dengan beban kerja karyawan. Pemberian kompensasi yang baik, layak, dan adil akan meningkatkan performa loyalitas karyawan yang dilakukan karyawan saat bekerja di Bellevue Heritage Villas Nusa Dua, Bali.

Ketiga, dapat diketahui bahwa karyawan memiliki rasa saling percaya terhadap rekan sesama rekan kerja di Bellevue Heritage Villas Nusa Dua, Bali. Perusahaan diharapkan tetap menjaga iklim organisasi dengan baik, sehingga karyawan akan tetap loyal bekerja di Bellevue Heritage Villas Nusa Dua, Bali. Perusahaan dapat melakukannya dengan menjalin komunikasi yang baik, dan lebih sering mengadakan kegiatan bersama para karyawan seperti games, outbond, temu 
keluarga karyawan yang nantinya akan membuat para karyawan akan semakin akrab dan nyaman sesama rekan kerja.

Berdasarkan pada penelitian yang telah dilakukan, keterbatasan penelitian ini adalah, antara lain : 1) Ruang lingkup penelitian yang sempit karena hanya mencakup lingkungan perusahaan Bellevue Heritage Villas Nusa Dua, Bali saja. 2) Generalisasi data terbatas, sebab jumlah data penelitian hanya terkumpul 40 orang karyawan Bellevue Heritage Villas Nusa Dua, Bali. 3) Peneliti hanya menguji pengaruh faktor organisasi yaitu pengembangan karir, kompensasi, dan iklim organisasi, sedangkan masih banyak faktor non organisasi yang dapat mempengaruhi loyalitas karyawan.

\section{SIMPULAN}

Simpulan dari penelitian ini berdasarkan hasil analisis dan pembahasan adalah sebagai berikut: 1) Pengembangan karir berpengaruh positif terhadap loyalitas karyawan Bellevue Heritage Villas Nusa Dua, Bali. Hal ini menunjukkan semakin baik pengembangan karir maka loyalitas karyawan juga akan meningkat. 2) Kompensasi berpengaruh positif terhadap loyalitas karyawan Bellevue Heritage Villas Nusa Dua, Bali. Hal ini menunjukkan semakin baik pemberian kompensasi di perusahaan maka loyalitas karyawan juga akan meningkat. 3) Iklim organisasi berpengaruh positif terhadap loyalitas karyawan Bellevue Heritage Villas nusa Dua, Bali. Hal ini menunjukkan apabila iklim organisasi di perusahaan semakin baik maka loyalitas karyawan juga akan meningkat.

Saran yang dapat diberikan berdasarkan hasil analisis dan pembahasan adalah sebagai berikut : 1) Pihak Bellevue Heritage Villas Nusa Dua, Bali hendaknya dapat lebih memberi informasi dan dukungan mengenai pengembangan karir, karena ketika karyawan mendapatkan peluang untuk pengembangan karir dengan begitu karyawan akan lebih meningkatkan loyalitasnya dalam bekerja untuk perusahaan. 2). Pihak Bellevue Heritage Villas Nusa Dua, Bali diharapkan memberi gaji, insentif, tunjangan yang disesuaikan dengan beban kerja yang dimiliki oleh karyawan. 3) Pihak Bellevue Heritage Villas Nusa Dua, Bali diharapkan dapat membuat lingkungan kerja yang nyaman mulai dari meningkatkan komunikasi, menunjukkan perilaku yang baik, bersikap jujur, memberi kebebasan karyawan dalam menyampaikan pendapat sehingga karyawan tetap bertahan untuk bekerja dengan demikian loyalitas karyawan akan semakin meningkat di Bellevue Heritage Villas Nusa Dua, Bali. 4) Peneliti selanjutnya yang melakukan penelitian serupa dapat memperluas cakupan lokasi dan diharapkan untuk mengkaji lebih banyak sumber maupun referensi serta mempertimbangkan variabel-variabel lain yang dapat mempengaruhi loyalitas karyawan.

\section{REFERENSI}

Aityan, S. K., \& Gupta. (2011). Challenges of Employee Loyalty in Corporate America. Journal Research Article, Accepted Version, 2(2), 47-54. 
Armanu, A., W, M. A. D. I., \& Sudjatno, S. (2017). the Effect of Direct and Indirect Compensation To Motivation and Loyalty of the Employee. Jurnal Aplikasi Manajemen, 15(1), 25-32. https://doi.org/10.18202/jam23026332.15.1.04

Bangun, W. (2012). Manajemen Sumber Daya Manusia. Jakarta: Penerbit Erlangga.

Cahyono, E. A., \& Adnyani, I. G. A. D. (2014). Pengaruh Gaya Kepemimpinan, Motivasi Kerja dan Iklim Organisasi Terhadap Prestasi Kerja Karyawan Bagian Engeneering Pada PT. Arabikatama Khatulistiwa Fishing Industry Denpasar. Fakultas Ekonomi Dan Bisnis, 2784-2798.

Cropanzano, R., \& Mitchell, M. S. (2005). Social exchange theory: An Interdisciplinary review. Journal of Management, 31(6), 874-900. https://doi.org/10.1177/0149206305279602

Dessler, G. (2015). Human Resource Management. Jakarta: Salemba Empat.

Dewi. (2016). Pengaruh Iklim Organisasi Terhadap Loyalitas Kerja Karyawan Hotel Benteng Pekanbaru Riau. Jom Fisip, 3(1), 14.

Evawati. (2013). Pengaruh Budaya Organisasi Terhadap Loyalitas Perawat Bagian Anak Rumah Sakit Umum Daerah Tanggerang. Jurnal Ilmu Ekonomi Dan Sosial, 1(3), 233-355.

Florence, K. (2010). The Effect of Employee Career Development on Performance of Public Primary Schools in Kenya: A Case of Starehe District, Nairobi County. Kenyatta Univesity.

Frimansah, M., \& Santy, R. (2011). Pengaruh Iklim Organisasi Dan Karakteristik Pekerjaan Terhadap Kepuasan Kerja Pegawai Di Lingkungan Pemerintahan Daerah Kabupaten Sukabumi. Majalah Ilmiah UNIKOM, 6(2), 225-233.

Handayani, T. (2015). Pengaruh Kompensasi terhadap Kinerja Guru. Utilitas, 1(1), 24-34.

Harlie, M. (2012). Jurusan aplikasi manajemen : JAM. Jurnal Aplikasi Manajemen, $\begin{array}{lcr}10(4), & 860-867 . & \text { Retrieved } \\ \text { http://jurnaljam.ub.ac.id/index.php/jam/article/view/473 }\end{array}$

Haryani, P. Y. (2008). Dengan Motivasi Kerja Dan Keinginan, 183-190.

Intifada, K. Y. (2013). KINERJA GURU MELALUI KEPUASAN KERJA GURU PADA SMA NEGERI 3 JEMBER KINERJA GURU MELALUI KEPUASAN KERJA GURU.

Jyoti, J. (2016). Impact of Organizational Climate on Job Satisfaction, Job Commitment and Intention to Leave: An Empirical Model. Journal of Business Theory and Practice, 1(1), 66. https://doi.org/10.22158/jbtp.v1n1p66

Kaseger, R. G. (2013). Pengembangan Karir dan Self Efficacy Terhadap Kinerja Karyawan Pada PT.Matahari Departement Store Manado Town Square. 
Jurnal Ekonomi Manajemen Bisnis Dan Akuntansi, 1(4), 906-916.

Kurniawan, S., Rahayu, \& Vebriana, T. (2013). Pengaruh Kepemimpinan, Lingkungan Kerja Dan Kompensasi Terhadap Kinerja Karyawan di PT. PLN Cabang Madiun. Jurnal Ekonomi Dan Manajemen Bisnis, 1(1).

Leblecbici, D. (2012). Impact of Workplace Quality on Employee'S Productivity: Case Study of a Bank in Turkey. Journal of Business,Economics\&Finance, $1(1), 38-49$.

Martiwi, R. T., \& Mardalis, A. (2013). Faktor - Faktor Penentu Yang Mempengaruhi, 13(1).

Murali, S., Poddar, A., \& Seema, A. (2017). Employee Loyalty, Organizational Performance \& Performance Evaluation - A Critical Survey. IOSR Journal of Business and Management Ver . III, 19(8), 2319-7668. https://doi.org/10.9790/487X-1908036274

Mursita, W. (2015). Pengaruh Iklim Organisasi terhadap Loyalitas Karyawan pada Hotel Ratu Mayang Garden Pekanbaru. Jom Fisip, 2(2).

Permatasari, I. R. (2006). Pengaruh Pengembangan Karir Terhadap Kinerja Karyawan. Modernisasi, 2(3), 177-191. https://doi.org/http://dx.doi.org/10.21067/jem.v2i3.921

Purwandari, E. Y. (2008). Pengaruh Kompensasi, Lingkungan Kerja, dan Gaya Kepemimpinan Terhadap Loyalitas Karyawan, 16.

Rahimic, Z. (2013). Influence of Organizational Climate on Job Satisfaction in Bosnia and Herzegovina Companies. International Business Research, 6(3), 129-139. https://doi.org/10.5539/ibr.v6n3p129

Ramadhani, Z. P., \& Rahardjo, M. (2017). ( Studi pada Kantor Direksi PT Perkebunan Nusantara IX Divisi Tanaman Tahunan ), 6, 1-12.

Simbolon, B. (2015). Pengaruh Motivasi Terhadap Loyalitas Kerja Karyawan Bagian Marketing Pada PT. Agung Automall Cabang Pekanbaru. JOM FISIP, 2(1), 1-10.

Suarningsih, N.L.P., Alamsyah, A., Thoyib, A. (2011). Pengaruh Iklim Organisasi terhadap Komitmen Organisasional dan Kinerja Karyawan di Rumah Sakit. Jurnal Aplikasi Manajemen, 2(66), 233-240.

Sullaida. (2010). Pengaruh Iklim Organisasi Terhadap Kepuasan Kerja Karyawan di PT. PLN Cabang Lhokseumawe. Jurnal Aplikasi Manajemen, 8(3), 700707.

Wibawa, I. M. A., \& Stephani. (2014). Pada Loyalitas Karyawan Berdasarkan, (1), 3078-3095.

Wicoksono, P. (2013). Vol. 01 No. 01, Juni 2013. Pendidikan Ekonomi IKIP Veteran Semarang, 01(01), 48-58. 
Aityan, S. K., \& Gupta. (2011). Challenges of Employee Loyalty in Corporate America. Journal Research Article, Accepted Version, 2(2), 47-54.

Armanu, A., W, M. A. D. I., \& Sudjatno, S. (2017). the Effect of Direct and Indirect Compensation To Motivation and Loyalty of the Employee. Jurnal Aplikasi Manajemen, 15(1), 25-32. https://doi.org/10.18202/jam23026332.15.1.04

Bangun, W. (2012). Manajemen Sumber Daya Manusia. Jakarta: Penerbit Erlangga.

Cahyono, E. A., \& Adnyani, I. G. A. D. (2014). Pengaruh Gaya Kepemimpinan, Motivasi Kerja dan Iklim Organisasi Terhadap Prestasi Kerja Karyawan Bagian Engeneering Pada PT. Arabikatama Khatulistiwa Fishing Industry Denpasar. Fakultas Ekonomi Dan Bisnis, 2784-2798.

Cropanzano, R., \& Mitchell, M. S. (2005). Social exchange theory: An Interdisciplinary review. Journal of Management, 31(6), 874-900. https://doi.org/10.1177/0149206305279602

Dessler, G. (2015). Human Resource Management. Jakarta: Salemba Empat.

Dewi. (2016). Pengaruh Iklim Organisasi Terhadap Loyalitas Kerja Karyawan Hotel Benteng Pekanbaru Riau. Jom Fisip, 3(1), 14.

Evawati. (2013). Pengaruh Budaya Organisasi Terhadap Loyalitas Perawat Bagian Anak Rumah Sakit Umum Daerah Tanggerang. Jurnal Ilmu Ekonomi Dan Sosial, 1(3), 233-355.

Florence, K. (2010). The Effect of Employee Career Development on Performance of Public Primary Schools in Kenya: A Case of Starehe District, Nairobi County. Kenyatta Univesity.

Frimansah, M., \& Santy, R. (2011). Pengaruh Iklim Organisasi Dan Karakteristik Pekerjaan Terhadap Kepuasan Kerja Pegawai Di Lingkungan Pemerintahan Daerah Kabupaten Sukabumi. Majalah Ilmiah UNIKOM, 6(2), 225-233.

Handayani, T. (2015). Pengaruh Kompensasi terhadap Kinerja Guru. Utilitas, 1(1), 24-34.

Harlie, M. (2012). Jurusan aplikasi manajemen : JAM. Jurnal Aplikasi Manajemen, 10(4), 860-867. Retrieved from http://jurnaljam.ub.ac.id/index.php/jam/article/view/473

Haryani, P. Y. (2008). Dengan Motivasi Kerja Dan Keinginan, 183-190.

Intifada, K. Y. (2013). KINERJA GURU MELALUI KEPUASAN KERJA GURU PADA SMA NEGERI 3 JEMBER KINERJA GURU MELALUI KEPUASAN KERJA GURU.

Jyoti, J. (2016). Impact of Organizational Climate on Job Satisfaction, Job Commitment and Intention to Leave: An Empirical Model. Journal of Business Theory and Practice, 1(1), 66. https://doi.org/10.22158/jbtp.v1n1p66 
Kaseger, R. G. (2013). Pengembangan Karir dan Self Efficacy Terhadap Kinerja Karyawan Pada PT.Matahari Departement Store Manado Town Square. Jurnal Ekonomi Manajemen Bisnis Dan Akuntansi, 1(4), 906-916.

Kurniawan, S., Rahayu, \& Vebriana, T. (2013). Pengaruh Kepemimpinan, Lingkungan Kerja Dan Kompensasi Terhadap Kinerja Karyawan di PT. PLN Cabang Madiun. Jurnal Ekonomi Dan Manajemen Bisnis, 1(1).

Leblecbici, D. (2012). Impact of Workplace Quality on Employee'S Productivity: Case Study of a Bank in Turkey. Journal of Business,Economics\&Finance, $1(1), 38-49$.

Martiwi, R. T., \& Mardalis, A. (2013). Faktor - Faktor Penentu Yang Mempengaruhi, 13(1).

Murali, S., Poddar, A., \& Seema, A. (2017). Employee Loyalty , Organizational Performance \& Performance Evaluation - A Critical Survey. IOSR Journal of Business and Management Ver . III, 19(8), 2319-7668. https://doi.org/10.9790/487X-1908036274

Mursita, W. (2015). Pengaruh Iklim Organisasi terhadap Loyalitas Karyawan pada Hotel Ratu Mayang Garden Pekanbaru. Jom Fisip, 2(2).

Permatasari, I. R. (2006). Pengaruh Pengembangan Karir Terhadap Kinerja Karyawan. Modernisasi, 2(3), 177-191. https://doi.org/http://dx.doi.org/10.21067/jem.v2i3.921

Purwandari, E. Y. (2008). Pengaruh Kompensasi, Lingkungan Kerja, dan Gaya Kepemimpinan Terhadap Loyalitas Karyawan, 16.

Rahimic, Z. (2013). Influence of Organizational Climate on Job Satisfaction in Bosnia and Herzegovina Companies. International Business Research, 6(3), 129-139. https://doi.org/10.5539/ibr.v6n3p129

Ramadhani, Z. P., \& Rahardjo, M. (2017). ( Studi pada Kantor Direksi PT Perkebunan Nusantara IX Divisi Tanaman Tahunan ), 6, 1-12.

Simbolon, B. (2015). Pengaruh Motivasi Terhadap Loyalitas Kerja Karyawan Bagian Marketing Pada PT. Agung Automall Cabang Pekanbaru. JOM FISIP, 2(1), 1-10.

Suarningsih, N.L.P., Alamsyah, A., Thoyib, A. (2011). Pengaruh Iklim Organisasi terhadap Komitmen Organisasional dan Kinerja Karyawan di Rumah Sakit. Jurnal Aplikasi Manajemen, 2(66), 233-240.

Sullaida. (2010). Pengaruh Iklim Organisasi Terhadap Kepuasan Kerja Karyawan di PT. PLN Cabang Lhokseumawe. Jurnal Aplikasi Manajemen, 8(3), 700707.

Wibawa, I. M. A., \& Stephani. (2014). Pada Loyalitas Karyawan Berdasarkan, (1), 3078-3095. 
Ni Putu Dian Purnamasari, Pengaruh Pengembangan Karir....

Wicoksono, P. (2013). Vol. 01 No. 01, Juni 2013. Pendidikan Ekonomi IKIP Veteran Semarang, 01(01), 48-58. 